\title{
The Geology of the Faraday 3 kimberlite, Kennady Lake, NWT Canada.
}

\author{
Dan Gainer ${ }^{1}$, Casey Hetman ${ }^{2}$, Michael Diering ${ }^{3}$ \\ ${ }^{1}$ Aurora Geosciences Ltd., Yellowknife, Canada, dan.gainer@aurorageosciences.com \\ ${ }^{2}$ SRK Consulting, Vancouver, Canada, chetman@srk.com \\ ${ }^{3}$ SRK Consulting, Vancouver, Canada, mdiering@srk.com
}

\section{Introduction}

The diamondiferous Faraday 3 body is one of four pipes identified in the Kelvin- Faraday cluster. It sits three kilometers north of the main Kelvin kimberlite and is $10 \mathrm{~km}$ from the recently constructed Gahcho Kué diamond mine within the Archean Slave Craton in northern Canada. Emplaced along the same structural trend as the other kimberlites in the cluster, Faraday 3 intrudes into gneissic basement comprised of metaturbidites of the Yellowknife Supergroup with minor amphibolite and narrow diabase dikes. Archean granitoids occur immediately to the west of the kimberlite cluster. Similar to the other kimberlite bodies in the Kelvin-Faraday cluster, Faraday 3 is described as a tubular, sub-horizontal, inclined pipe dominantly infilled with volcaniclastic kimberlite. It contains multiple kimberlite phases resulting from various emplacement events. Presently it is drill defined as 300 meters long, 30 meters in height and 70 meters wide.

\section{Evaluation}

Extensive geophysical surveys, 59 diamond drill holes and 42, 11-inch diameter reverse circulation (RC) drill holes have defined the external shape of the body. Microdiamond sampling of drill core has revealed that the body is significantly diamondiferous. Detailed logging and clast abundance measurements on the drill core have revealed a complex internal geology. This work is reinforced by a petrological investigation of 163 kimberlite thin sections and 44 country rock thin sections from 16 diamond drill holes selected across the body. Following this investigation a 3D model was generated in Leapfrog (Figure 1). A total of 3.16 tonnes of kimberlite recovered by core drilling was processed for microdiamonds by caustic fusion at the Geoanalytical Laboratories Diamond Services of the Saskatchewan Research Council ("SRC") to return a sample grade of 2.18 carats per tonne. The diamond recoveries are presented in Table 1 below.

\begin{tabular}{|c|c|c|c|c|c|c|c|c|c|c|c|c|c|c|c|}
\hline \multirow[b]{2}{*}{ Unit } & \multirow[b]{2}{*}{$\begin{array}{c}\text { Sample } \\
\text { Weight (dry } \\
\text { tonnes) }\end{array}$} & \multicolumn{12}{|c|}{ Number of Diamonds According to Sieve Size Fraction (mm) } & \multirow[b]{2}{*}{$\begin{array}{c}\text { Total } \\
\text { Stones }\end{array}$} & \multirow[b]{2}{*}{$\begin{array}{c}\text { Total } \\
\text { Carats } \\
(+0.85 \mathrm{~mm}) \\
\end{array}$} \\
\hline & & $\begin{array}{l}+0.106 \\
-0.150\end{array}$ & $\begin{array}{l}+0.150 \\
0.212\end{array}$ & $\begin{array}{l}+0.212 \\
-0.300\end{array}$ & \begin{tabular}{|l|}
+0.30 \\
$0-$ \\
0.425 \\
\end{tabular} & \begin{tabular}{|l|}
+0.42 \\
$5-$ \\
0.600 \\
\end{tabular} & \begin{tabular}{|l|}
+0.60 \\
$0-$ \\
0.850 \\
\end{tabular} & \begin{tabular}{|l|}
+0.85 \\
$0-$ \\
1.180
\end{tabular} & \begin{tabular}{|l|}
+1.18 \\
$0-$ \\
1.700
\end{tabular} & \begin{tabular}{|l|}
+1.70 \\
$0-$ \\
2.360
\end{tabular} & \begin{tabular}{|l|}
+2.36 \\
$0-$ \\
3.350
\end{tabular} & \begin{tabular}{|l|}
+3.35 \\
$0-$ \\
4.750
\end{tabular} & \begin{tabular}{|l|}
+4.75 \\
$0-$ \\
6.700 \\
\end{tabular} & & \\
\hline KDYKE & 0.0512 & 222 & 154 & 80 & 41 & 25 & 17 & 8 & 3 & - & - & - & - & 550 & 0.1347 \\
\hline KIMB1 & 0.1965 & 531 & 365 & 212 & 145 & 65 & 39 & 16 & 10 & 8 & - & - & - & 1,391 & 1.0764 \\
\hline KIMB2 & 0.1484 & 206 & 165 & 82 & 45 & 24 & 15 & 11 & 6 & 1 & - & - & - & 555 & 0.4009 \\
\hline KIMB3 & 0.0822 & 47 & 31 & 21 & 13 & 8 & 2 & 2 & - & - & - & - & - & 124 & 0.0243 \\
\hline KIMB4 & 2.4712 & 1,456 & 964 & 555 & 332 & 178 & 94 & 51 & 23 & 10 & 9 & 1 & - & 3,673 & 4.6461 \\
\hline MB & 0.0885 & 22 & 18 & 11 & 8 & 1 & 1 & 1 & 1 & . & - & - & - & 63 & 0.0259 \\
\hline
\end{tabular}

Table 1: Diamond results by phase for the main pipe infills. Minor phases are not listed. 

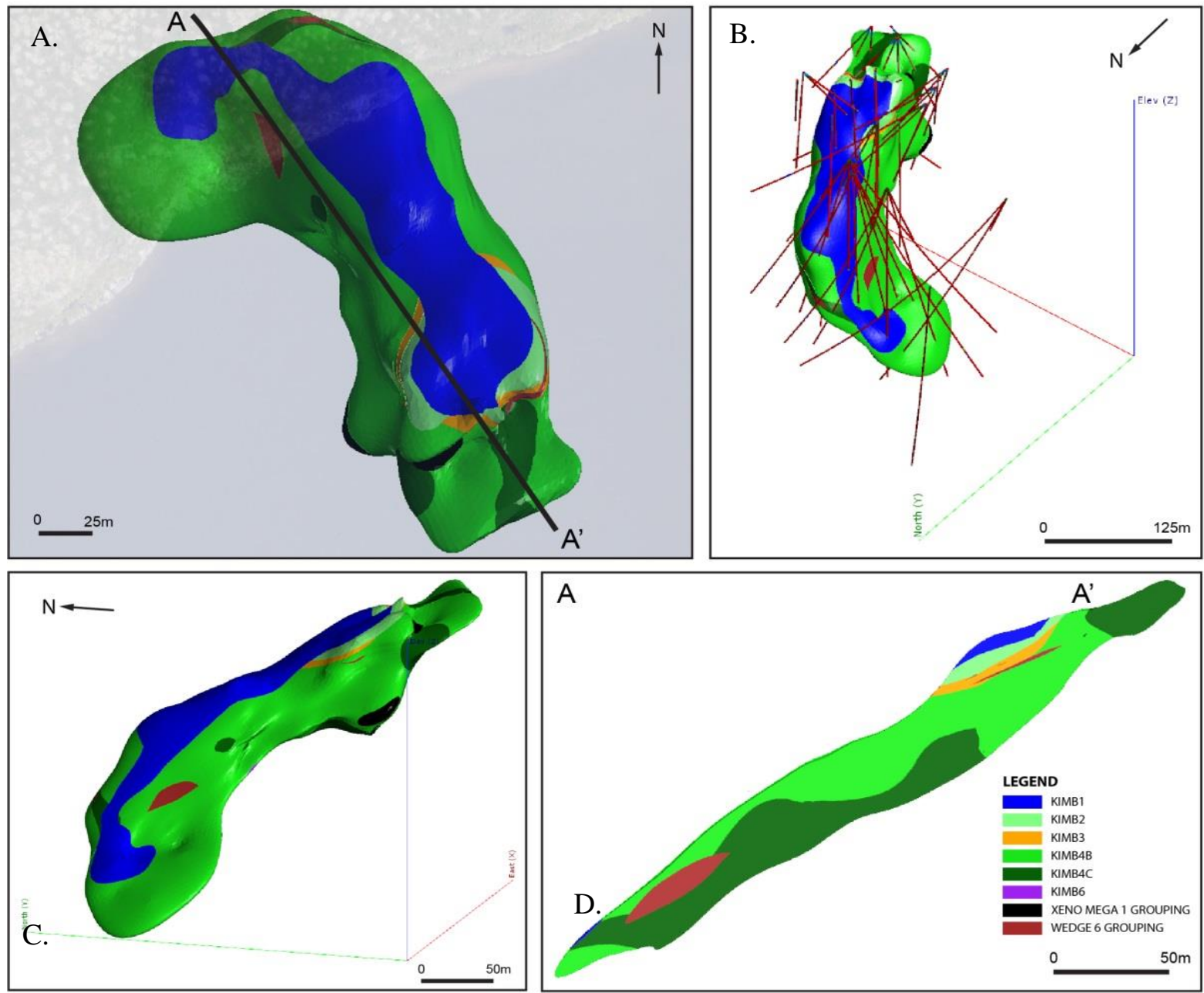

Figure 1: 3D model of the Faraday 3 kimberlite pipe. (A) Plan view; (B) Oblique view of the Faraday 3, looking southeast, with the traces of diamond drill; (C) Detailed geology model of Faraday 3 looking northeast; KIMB1, a hypabyssal kimberlite (HK); KIMB2, a uniform volcaniclastic kimberlite (VK); KIMB3, a well sorted volcaniclastic kimberlite (VK); In-situ gneissic wedges; and KIMB4, a highly variable VK with respect to country rock dilution. KIMB4 has been subdivided into KIMB4A ( $<25 \%$ dilution) not modelled, KIMB4B (25-75\% dilution) and KIMB4C (>75\% dilution). (D) Long section of Faraday 3 looking northeast.
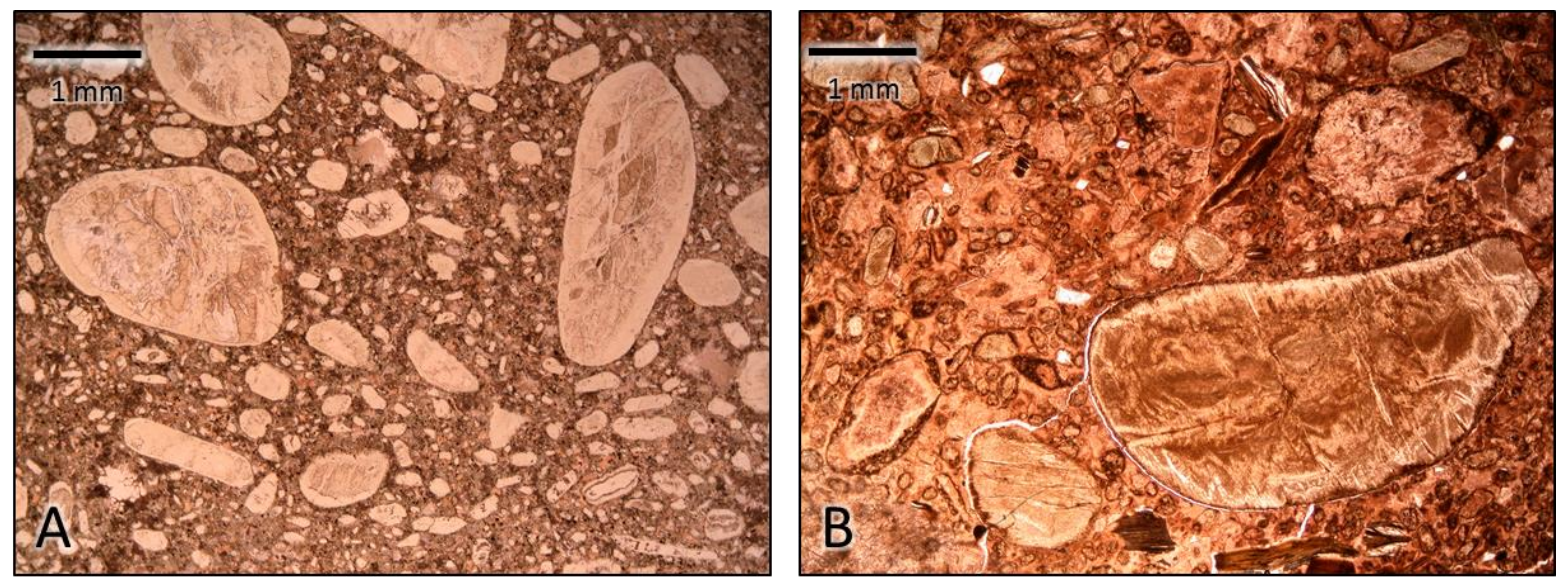

Figure 2: Photomicrographs of the two textural end-members present at Faraday 3. A) Coherent phlogopite kimberlite (KIMB1); note the uniform distribution of olivines altered to serpentine and carbonate set within a groundmass of monticellite> phlogopite> carbonate> spinel> perovskite. B) Volcaniclastic phlogopite kimberlite (KIMB2); olivine rich with thin melt selvedges and common fresh country rock xenoliths set within an altered microlitic matrix with abundant serpentine. 


\section{Geology}

Four kimberlite domains have been modeled in the body: KIMB1, a HK comprised of at least 2 unique phases of kimberlite, one is dominated by a phlogopite groundmass while the other phase contains conspicuous monticellite in the groundmass; KIMB2, a uniform VK; KIMB3, a well sorted VK associated with in-situ gneissic wedges which displays flow features; and KIMB4, a highly variable VK with respect to country rock dilution. KIMB4 has been subdivided into KIMB4A ( $<25 \%$ dilution), KIMB4B (25-75\% dilution) and KIMB4C ( $>75 \%$ dilution). The individual phases of kimberlite are related to separate emplacement events and occur in conformable layers. Discrete, unique intervals of volcaniclastic kimberlite, HK sheets and marginal breccias also surround the body. Based on the current drilling, the main pipe infills that occupy the majority of the pipe are KIMB4B, followed by KIMB4C and then KIMB1. The VK infill is characterized by thin skinned pelletal shaped magmaclasts (formally termed pelletal lapilli) set within a serpentine and microlite dominated interclast matrix with common fresh to variably altered locally derived country rock xenoliths and xenocrysts. Mantle derived indicator minerals are rarely encountered within the drill cores and include peridotitic and less common eclogitic garnets and no ilmenite has been identified.

\section{Conclusions}

Following detailed petrography, KIMB2 and KIMB4 are further classified as Kimberley type pyroclastic kimberlite (KPK), formerly called tuffisitic kimberlite breccia (TKB) (Smith et al., 2013). KIMB3 has not been classfied as such due to the presence of layering. This material is interpreted to represent a zone of flow or a volatile escape feature associated with a contact against in-situ wedges of country rock.

The textures, general geology and preliminary diamond results obtained from Faraday 3 are similar to those published from the Gahcho Kué mine to the south (Hetman et al., 2004). Only the inclined nature of Faraday 3 differs from the emplacement of the Gahcho Kué kimberlites

It is presently unclear if Faraday 1 and 3 volcaniclastic rocks are connected at depth; they share many similarities however further work is required before the relationship (if any) between these rocks can be determined.

Faraday 3 has an average grade of 2.18 carrats per tonne based on microdiamond analyis, however in 2017, 42 11-inch large diamond RC drill holes were completed and a 262 tonne bulk sample was collected for the purpose of obtaining a macrodiamond parcel for preliminary grade and diamond value estimates. The macrodiamond results from the 2017 program will be combined with previous data to support a possible resource classification for Faraday 3.

\section{References}

Hetman, C. M., Smith, B. S., Paul, J. L., \& Winter, F. (2004). Geology of the Gahcho Kue kimberlite pipes, NWT, Canada: root to diatreme magmatic transition zones. Lithos, 76(1), 51-74.

Smith, B. S., Nowicki, T. E., Russell, J. K., Webb, K. J., Mitchell, R. H., Hetman, C. M., and Robey, J. A. (2013). Kimberlite terminology and classification. In Proceedings of 10th International Kimberlite Conference (pp. 1-17). Springer India 